\title{
AN EXPERT SYSTEM APPROACH FOR THE INTERNAL AUDIT OF ISO 9001: 2015
}

\author{
DOI: 10.17261/Pressacademia.2018.854 \\ PAP- V.7-2018(7)-p.47-51
}

Emine Kizmaz ${ }^{1}$, Esma Deveci², Huseyin Selcuk Kilic ${ }^{3}$

${ }^{1}$ Marmara University, Goztepe Yerleskesi 34722 Kadıköy, Istanbul, Turkey. eminekizmaz@marun.edu.tr, ORCID: 0000-0002-0009-6175

${ }^{2}$ Marmara University, Goztepe Yerleskesi 34722 Kadıköy, Istanbul, Turkey. esmadeveci@marmara.edu.tr, ORCID: 0000-0002-6601-9922

${ }^{3}$ Marmara University, Goztepe Yerleskesi 34722 Kadıköy, Istanbul, Turkey. huseyin.kilic@marmara.edu.tr, ORCID: 0000-0003-3356-0162

To cite this document

Kizmaz, E., Deveci, E., Kilic, H. S. (2018) An expert system approach for the internal audit of ISO 9001: 2015. PressAcademia Procedia (PAP), V.7, p.47-51.

Permemant link to this document: http://doi.org/10.17261/Pressacademia.2018.854

Copyright: Published by PressAcademia and limited licenced re-use rights only.

\section{ABSTRACT}

Purpose- This research proposes an expert system approach for the internal audit of ISO 9001: 2015.

Methodology- The International Organization for Standardization (ISO) 9001 Certificate is one of the main indicators of a good organization. One of the important steps of providing ISO 9001 quality management system is the internal audit. Depending on its importance, this study aims to facilitate the internal audit process with respect to ISO 9001: 2015 accreditation via Expert System approach. Expert systems are knowledge based systems which can be as successful as human experts in the solution of complicated problems by utilizing the expertise and knowledge of experts. However, rule based approach is used in the proposed expert system.

Findings- The internal audit evaluations and scoring reports regarding ISO 9001: 2015 directives are obtained as a result of the expert system.

Conclusion- The study provides an expert system for internal audit of ISO 9001: 2015 which is essential for all the organizations. With the proposed expert system, the organizations will be able to operate the internal audit process in a systematic way without the need of an expert. Moreover, the deficiencies that do not comply with ISO requirements can be easily identified.

Keywords: Expert system, internal audit, ISO 9001: 2015

JEL Codes: L15, L50, O31

\section{INTRODUCTION}

Expert systems are computer programs with intelligence and knowledge that resemble field experts in the solution of problems in a particular complex area. Initial work on expert systems began in the late 1950s, and nowadays many areas are being used, including medicine, geology, mathematics, chemistry, computer technology, management and military. The fact that the speed of change in technology and science is high today has brought the needs of experts in various fields to the highest level. The intense competition environment requires the right information, fast and at the lowest possible cost. The fact that the number of experts working on quality is low, the time it takes for quality specialists to grow up and the cost of operating these people is costly, has led to the idea of developing expert systems in this field.

The objective of this study is to suggest an expert system approach for facilitating the internal audit process with respect to ISO $9001: 2015$ QMS. ISO 9001 QMS Standardization is one of the standards of quality assurance system that has been widely accepted today. Implementation and continuity of ISO 9001 QMS require expertise for all organizations which are producing products and services. The continuity of the quality system established in the organizations must be ensured. It is important that internal audits are carried out to ensure that the ISO 9001 structure is applied at this stage and the sustainability of the ISO 9001 organization is ensured. In addition, these internal audits determine the deficiencies in the system, but there is no study to measure the audited ISO 9001 QMS sensitivity and system success. ISO 9001: 2008 QMS Standards are updated to ISO 9001:2015 QMS Standards. The firms must adapt their existing QMSs according to the standards of ISO 9001: 2015 until September 15, 2018 (URL 1).

In this study, an expert system approach for measuring the success of the ISO 9001 QMS items and the system in general is proposed. With this expert system approach, internal audits can be performed more quickly and the system's performance can be measured. The remainder of this study is organized as follows: "Section 2" includes the literature review. "Section 3 " provides the data and methodology. Findings are provided in "Section 4" and finally "Section 5" contains the conclusion with the references following. 


\section{LITERATURE REVIEW}

Literature review of this study is based on two parts. The first one is Quality Management System (QMS) and the other one is Expert Systems (ES). Hence, the related studies about these two main topics are as below.

\subsection{Quality Management System (QMS)}

The concept of quality has been used since ancient times, especially after the industrial revolution, with the increase of mechanization, the production style has shifted from workshop type production to factory production and mass production. With the change of many inhabitants living, the quality conceptually emerged in the 19th century (Montgomery, 2009).

Many developments happened related with quality. Juran published Quality Control Handbook (1951) and separated the quality into two components: first one is quality of design and the other one is quality of conformance (Reeves and Bednar, 1994). Deming and Juran went to Japan to provide quality-related lectures. Deming pointed out that many problems arising from production originated from the process, and that this could be controlled using statistical methods. Juran set up a managerial approach to quality control and focused on projectbased teamwork and client satisfaction. Crosby revealed the concept of "zero error" (Günaydın, 2001). Moreover, at the end of the 1980s, the automotive industry started to apply Statistical Process Control (SPC). The Malcolm Baldrige National Quality Award (1986) for American companies and the European Quality Foundation (EFQM) quality award for European companies began in 1992 (Boran, 2000 ).

Regarding the quality management systems, International Organization for Standardization (ISO) is the world's grand developer of quality standards. ISO, was set up in Geneva, Switzerland in 1947. The International Standards which ISO develop are very beneficial. This is because it conduces to making the development, manufacturing and supply of products and services more effective, confident and cleaner (Shouman et al., 2009). Gotzamani and Tsiotras (2001) emphasize that ISO 9000 standards enable companies to design and utilize an efficient and active quality system with the consideration of continuous improvement and adaptation. Arditi and Gunaydın (1997) point out that the ISO 9000 standards are composed of two basic concepts including quality management and quality assurance. However, besides implementing ISO standards to the company, the internal audit is also important. Internal audit is a function that controls and analyzes the processes and procedures within the organization, suggests improvement, performs risk analysis, and serves all the interest groups both inside and outside the company (Aslan and Özçelik, 2012). According to Türedi (2012), total quality management and internal auditing are two mutually reinforcing management elements that progress through innovations in achieving the company's goals and they are in interaction and help each other to develop. Hence, depending on its importance, it is focused on internal audit in this study.

\subsection{Expert Systems (ES)}

Expert systems are problem-solver or decision-maker software packets that could achieve a stage of performance commonly in attenuated problem areas. Expertise is transferred to the computer from experts. This transmitted information is kept in the computer. Then users operate the computer for particular suggestions as required. The expert system inquiries about cases and could make inferences and attain to a particular result. Afterwards, such as a human advisor, it informs one who is not a specialist and declares, if required, the logic underlying the suggestion (Aronson et al., 2005).

Initial work on the expert system began towards the end of 1950s and the leading system in this field is DENDRAL. This system was initiated in 1965 by E. Feigenbaum and colleagues at Stanford University in the USA to provide assistance in the identification of the structure of an organic compound by mass spectrogram and raw chemical formula (Altuntaş and Çelik, 1998). Expert system methodologies are based on eleven parts including knowledge-based systems, rule-based systems, fuzzy expert systems, neural networks, case-based reasoning, objectoriented methodology, intelligent agent systems, system architecture, modeling, database methodology and finally ontology (Liao, 2005).

Regarding the structure of the expert systems, it can be stated that there is not a standard structure and the main reason why expert systems cannot have a standard structure is that each structure is more suitable for another application than the other. In general, although expert system structures differ from each other, the components that make up the expert system structure can be described as knowledge base, working memory, inference engine, explanatory system, knowledge acquisition facility and user interface (Fidan, 1994).

\section{DATA AND METHODOLOGY}

The aim of this study is primarily to develop an expert system that can be used by all companies. This expert system is a program established within the scope of ISO 9001: 2015 QMS, to use in internal audits and to measure achievement. With this program, the deficiencies of the QMS used can be identified. The accuracy of the output of this program depends on the truthfulness of the answers to the questions to be asked and their objectivity.

For this expert system, some rules were developed and all the rules were built on each part of the QMS. The weight points and the scoring structure were created and, as a result, the scoring structure was combined with the expert system. Thus, an expert system structure consisting of knowledge base, working memory, extraction engine, explanatory system, information acquisition facility and user interface was established and a system supporting the companies was established.

Knowledge acquisition facility is based on ISO 9001:2015 QMS Standards in proposed expert system approach. The knowledge base names and rule numbers are shown in Table 1 as follows. 
Table 1: Knowledge Bases and Number of Rules

\begin{tabular}{|c|c|c|}
\hline Knowledge Base Name & ISO 9001 Quality System Submission subject to Audit & Number of Rules \\
\hline Process 1 & Mannagement Responsibility Process & 24 \\
\hline Process 2 & Quality Management System Process & 26 \\
\hline Process 3 & Production (New Product) Process & 38 \\
\hline Process 4 & Purchasing Process & 20 \\
\hline
\end{tabular}

These rules constitute the knowledge base of the expert system. The questions created by these rules can be answered in three ways as "Yes, No or Partially". These responses are retrieved by the inference engine for use and sent to the working memory. Later the inference engine carries out the processes necessary for interrogating these knowledge bases by searching through the forward chained control strategy. The inference engine here, in order to initiate a rule, searches the case list for cases that satisfy the condition part of the rule, and performs the result part of that rule if it finds these cases.

The designed system consists of two parts which are intertwined; The Internal Audit Part (1) and The Success Measurement (Scoring) Part (2). ISO 9001 QMSs, expert systems and internal audit related literature search and consulted experts have played an important role to identify the problem. The questions are prepared by the information obtained from experts and the accreditation of ISO 9001 : 2015. Depending on the answers received from the user, the question flow can change.

In internal audit part, there is a knowledge base that belongs to 4 processes of organizations. Each knowledge base is divided into the questions determined within the scope of ISO 9001: 2015 standards. A number of different questions are asked to the user regarding the auditing of the system under each process heading.

The important point here is that the expert system determines the questions that the user will ask in the next step, according to the answer given by the user. In other words, the "No" answer given by the user to some questions may skip the next question and lead to other questions so it makes the expert system more complex. Depending on the problem type, the user is offered a choice of two kinds of answers; Yes / No or Yes / Partially / No.

The approach controlled by the four process expert systems does not have the same designation. At this point, each Weight Score (WS) of processes is determined by information from experts and by literature review. The weight scores of these operations are given in Table 2 below.

Table 2: Knowledge Bases and Weight Scores

\begin{tabular}{|c|c|c|}
\hline Knowledge Base Name & ISO 9001 Quality System Submission subject to Audit & Weight Score \\
\hline Process 1 & Mannagement Responsibility Process & 30 \\
\hline Process 2 & Quality Management System Process & 30 \\
\hline Process 3 & Production (New Product) Process & 24 \\
\hline Process 4 & Purchasing Process & 16 \\
\hline TOTAL SCORE & & 100 \\
\hline
\end{tabular}

Here, each process is determined according to the importance of the Weight Score (WS) in the process and the Quality Management Standards. The Process Score (PS) for each process is calculated as follows.

Process Total Score (Process TS) $=10 * \mathrm{Y}(\mathrm{Yes})+5 * \mathrm{P}($ Partially $)+0 * \mathrm{~N}(\mathrm{No})$

Process Maximum Score (Process MS) = number of questions answered * 10

Process Success Percentage $($ Process SP) $=$ Process TS * $100 /$ Process MS

Process Score (The value of the WS that corresponds to the Process' success) = Process WS* Process SP / 100

There are explanations in the software section of the program with respect to scoring information (section where constants and variables are assigned), functions, rules, score calculations, and module display sections found in this expert system. These explanations provide information about the processes that ensure the program to run and provide its results. This program is prepared using JAVA programming language.

The implementation of the proposed expert system approach under the ISO 9001 QMS in an enterprise is accomplished. The questions that is asked by the proposed expert system during the audit are directed to the relevant people and the responses received are entered into the expert system. 


\section{FINDINGS}

After the application the expert system in a company which is in the plastic sector, the related scores are obtained. Considering the $70 \%$ score as the base for success. There are not the processes with success percentage below $70 \%$. However, since, system final score is 90.5 $\%$ so, it can be said that the internal audit of the company is successful and passes the required score threshold.

Table 3: Summary Display of Implementation Results and Success Measurement of the Company

\begin{tabular}{|c|c|c|c|c|c|c|c|c|c|}
\hline \multicolumn{10}{|c|}{ AUDIT RESULTS } \\
\hline No & $\begin{array}{c}\text { Audited } \\
\text { Knowledge } \\
\text { Base }\end{array}$ & $\begin{array}{l}\text { \# of } \\
\text { "Y" }\end{array}$ & $\begin{array}{l}\text { \# of } \\
\text { "P" }\end{array}$ & $\begin{array}{l}\text { \# of } \\
\text { "N" }\end{array}$ & $\begin{array}{c}\text { Process } \\
\text { TS }\end{array}$ & $\begin{array}{c}\text { Process } \\
\text { MS }\end{array}$ & $\begin{array}{l}\text { Process } \\
\text { SP }\end{array}$ & $\begin{array}{l}\text { Process } \\
\text { Score }\end{array}$ & $\begin{array}{l}\text { Weight } \\
\text { Score } \\
\text { (WS) }\end{array}$ \\
\hline $\mathbf{1}$ & $\begin{array}{c}\text { Management } \\
\text { Responsibility } \\
\text { Process }\end{array}$ & 24 & 0 & 0 & 240 & 240 & 100 & 30.0 & 30 \\
\hline 2 & $\begin{array}{c}\text { Quality } \\
\text { Management } \\
\text { System } \\
\text { Process }\end{array}$ & 20 & 3 & 2 & 215 & 250 & 86 & 25.8 & 30 \\
\hline 3 & $\begin{array}{c}\text { Production } \\
\text { (New } \\
\text { Product) } \\
\text { Process }\end{array}$ & 29 & 4 & 2 & 310 & 350 & 88 & 21.3 & 24 \\
\hline 4 & $\begin{array}{c}\text { Purchasing } \\
\text { Process }\end{array}$ & 15 & 2 & 2 & 160 & 190 & 84 & 13.5 & 16 \\
\hline \multicolumn{9}{|c|}{ SYSTEM MAXIMUM SCORE (SYSTEM MS) } & 100 \\
\hline \multirow{2}{*}{\multicolumn{9}{|c|}{$\begin{array}{l}\text { SYSTEM SCORE (SYSTEM S) } \\
\text { ORE (SYSTEMES) = SYSTEM S }\end{array}$}} & 90.5 \\
\hline S) & TEM FINAL & & E (SY & & & 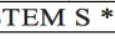 & & & 90.5 \\
\hline
\end{tabular}

\section{CONCLUSION}

Expert systems are knowledge based systems with software and hardware, which can be as successful as human experts solving complicated problems by using expertise and knowledge of experts. Expert systems have the benefits such as using time efficiently, reducing costs, increasing productivity, and reducing errors. The ISO 9001: 2015 standard anticipates continuous improvement, and also internal audit is one of the main processes that must be used for continuous improvement. In this study, the expert system approach is combined with the scoring technique to ensure that the quality systems of the companies are checked according to the ISO $9001: 2015$ standards before the quality control and the necessary improvements are made.

The proposed expert system is based on rules and knowledge. For this reason, questions are prepared with the information obtained from ISO and quality management experts and question lists of these processes were determined. Since the new ISO 9001 : 2015 accreditation is based on the process, the four main processes of the organizations are discussed. These processes have been prepared by extensive research and consultation of experts. Management Responsibility Process, Quality Management System Process, Production (New Product) Process, Purchasing Process are processes that are integrated into the system. The proposed system can carry out the internal audit process without the need for the experts. This reduces the cost. Also, companies often try to keep the internal audit process as short as possible because they do not want to waste their workforce. Moreover, the system performance can be measured together with the scoring system. Hence, this system provides time saving, increases productivity and continuity.

In the further studies, the expert system approach proposed in this study can be improved or modified depending on technological developments and developments in the ISO QMS processes. Accordingly, more compatible systems can be used instead of the JAVA programming language depending on the developments that may occur in the software system.

\section{REFERENCES}

Altuntaş, E., Çelik, T. (1998). Yapay zekanın tarihçesi. Otak Yayıncılık.

Arditi, D., Gunaydin, H. M. (1997). Total quality management in the construction process. International Journal of Project Management, 15(4), 235-243.

Aronson, J. E., Liang, T. P., Turban, E., (2005). Decision support systems and intelligent systems. Pearson Prentice-Hall.

Aslan, S., Özçelik, H. (2012). İç denetim ve toplam kalite yönetimi ilişkisi. Uluslararası Yönetim İktisat ve İşletme Dergisi, 5(10), 109-119.

Boran, S. (2000). Toplam kalite yönetimi.

Fidan, S. (1994). Endüstri mühendisliğinde uzman sistemler ve proje yönetim yazilimi seçiminde bir uzman sistem yaklaşimi. Doctoral Dissertation

Gotzamani, K. D., Tsiotras, G. D. (2001). An empirical study of the ISO 9000 standards' contribution towards total quality management. International Journal of Operations \& Production Management, 21(10), 1326-1342. 
Günaydın, H. M. (2001). Toplam kalite yönetimi. Mimarlar Odası İzmir Şubesi.

Liao, S. H., (2005). Expert system methodologies and applications-a decade review from 1995 to 2004. Expert systems with applications, 28(1), 93-103.

Montgomery, D. C. (2009). Introduction to statistical quality control. John Wiley \& Sons (New York).

Reeves, C. A., \& Bednar, D. A. (1994). Defining quality: alternatives and implications. Academy of management Review, 19(3), 419-445.

Shouman, M., Eldrandaly, K., \& Tantawy, A. (2009). Software quality assurance models and expert systems.

Türedi, S. (2012). İç kontrol sistemi ve toplam kalite yönetimi ilişkisi. Uluslararası Alanya İşletme Fakültesi Dergisi, 4(1).

URL 1: https://www.iso.org/iso-9001-revision.html (11.12.2017) 